Rev. Andrzej Kobylinski

Uniwersytet Kardynała Stefana Wyszyńskiego w Warszawie

\title{
Seeking a Virtuous Patriotism: Considerations on Love for One's Country
}

This article aims not only to present a few philosophical concepts of patriotism, but to also outline the broader context of contemporary disputes taking place in many countries regarding the relationship between man and his nation, state, and homeland. Although philosophy had not considered the question of patriotism for many years, within the past century this situation has changed drastically. Moral, political, and philosophical thinkers such as Dolf Sternberger, Alasdair Maclntyre, Jürgen Habermas, and Igor Primoratz have taken up this issue. Political philosophy's interest in patriotism is clearly evident in, among other things, the current dispute between communists and representatives of liberal thought.

Key words: patriotism, national patriotism, constitutional patriotism, homeland, nation, nationalism, solidarity, democracy, social ethics.

\section{Introduction}

Throughout history, many countries and nations have exhibited very diverse examples of patriotism. The proper understanding of love for one's country and heritage remains an interesting topic of debate in different regions of the world. At the beginning of the twenty-first century, a renaissance in patriotism occurred, inspiring philosophical and political discussions on this topic that have continued in the United States to this day. ${ }^{1}$ The political thinker Igor Primoratz's book

See S. P. Kiernan, Authentic Patriotism: Restoring America's Founding Ideals Through Selfless (New York: St. Martin's Press, 2010). 
Moral theology

entitled Patriotism contains an interesting and significant testament to this debate. ${ }^{2}$ More recently, important discussions about patriotism have been taking place in Poland, Germany, and Italy, ${ }^{3}$ while the leaders of Russia, India, and even China have acknowledge the need to foster and instill patriotic attitudes in their people.

In 2012, the Chinese Communist Party announced that patriotism would be included (along with freedom, equality, and sacrifice) among its so-called Core Socialist Values. In the years following, the authorities in Beijing added eight new values to this list: prosperity, democracy, courtesy, harmony, justice, rule of law, honesty, and friendship. To instill these important socialist values, teachers teach school children in the Middle Kingdom to write them by heart. In addition, the Chinese people sing songs and recite poems about patriotism and similar values. Additionally, the authorities in Beijing seek to ensure that patriotism is present in mass media and culture, on the streets, in homes, etc.

What is the essence of patriotism? Is every form of patriotism good? How does one differentiate between patriotic and nationalistic attitudes, between chauvinism and xenophobia? What does the American philosopher Alasdair MacIntyre think about patriotism? How does one evaluate the concept of constitutional patriotism in the German thinker Jürgen Habermas' publications? Does the Solidarity movement provide examples of sage patriotic attitudes? How can patriotism combine modernity and tradition?

The main purpose of this article is twofold: 1) to present a few philosophical concepts of patriotism and 2) to outline the broader context of contemporary disputes taking place in many countries regarding the proper understanding of the relationship between man and his own nation, state, and homeland.

\section{An American Understanding of Patriotism}

On March 26, 1984, the well-known American philosopher Alasdair MacIntyre gave a very important lecture on the topic of patriotism at the University of Kansas. MacIntyre's inspiring speech was published in English by the University of Kansas' Department of Philosophy and

2 See I. Primoratz, Patriotism (New York: Humanity Books, 2002).

3 See M. Rosati, Il patriottismo italiano. Culture politiche e identità nazionali [Italian Patriotism. Political Cultures and National Identities] (Rome: Bari, 2000); M. Król, Patriotyzm przyszłości (Warsaw: Rosner i Wspolnicy, 2004); A.M. Kobos, ed., Patriotyzm wczoraj i dziś (Cracow: Seminarium PAU, 2008). 
subsequently translated into many other languages. ${ }^{4}$ From then on, this important American intellectual's view of patriotism became the reference point for global public opinion. ${ }^{5}$

MacIntyre's lecture was included in the United State's extraordinarily rich tradition of patriotism, the spirit of which has been promoted and instilled in the American people at home and in schools, churches, social organizations, societies, etc., since the country's inception. From the American Revolution, which began in 1775, until the 1960s, patriotism united the entire American nation. This situation changed, however, during the second half of the twentieth century when the liberal and neo-Marxist milieu began to grow stronger throughout the Western world. With the hippie movement, sexual revolution of 1968, and the Vietnam War, patriotism became a controversial issue.

Since the 1960 s, some Americans have begun to claim that patriotism is not a virtue at all, but rather a vice and crime. The rejection of patriotism forced its proponents to devise new and convincing arguments to justify patriotism's moral value. In 1984, MacIntyre defended patriotism as a virtue connected to loyalty, stating:

Patriotism is defined in terms of a kind of loyalty to a particular nation which only those possessing that particular nationality can exhibit. Only Frenchmen can be patriotic about France, while anyone can make the cause of civilization their own. But it would be all too easy in noticing this to fail to make a second equally important distinction. Patriotism is not to be confused with a mindless loyalty to one's own particular nation which has no regard at all for the characteristics of that particular nation. Patriotism does generally and characteristically involve a peculiar regard not just for one's own nation, but for the particular characteristics and merits and achievements of one's own nation. These latter are indeed valued as merits and achievements and their character as merits and achievements provides reasons supportive of the patriot's attitudes. ${ }^{6}$

MacIntyre counted patriotism among the virtues that exhibit loyalty. Other virtues such as marital fidelity; love for one's family and nation; friendship; and respect for one's school, state, government institutions, sports clubs, etc. are all based on loyalty. MacIntyre confirms that actions based on loyalty cannot be reduced solely to an expression of

4 See. A. MacIntyre, Is Patriotism a Virtue? (Kansas: University of Kansas Press, 1984).

5 See F. Mangena, "Aristotle, Patriotism, and Reason: Reflections of MacIntyre's Question - Is Patriotism a Virtue?," Phronimon 11, no. 2 (2010): 5-48. 
Moral theology

gratitude. Of course, gratitude plays a certain role in loyal behavior, but its significance is very limited:

What patriotism and other such attitudes involve is not just gratitude, but a particular kind of gratitude; and what those who treat patriotism and other such loyalties as virtues are committed to believing is not that what they owe their nation or whomever or whatever it is is simply a requital for benefits received, based on some relationship of reciprocity of benefits.

So although one may as a patriot love one's country, or as a husband or wife exhibit marital fidelity, and cite as partially supporting reasons one's country's or one's spouse's merits and one's own gratitude to them for benefits received these can be no more than partially supporting reasons, just because what is valued is valued precisely as the merits of my country or spouse or as the benefits received by me from my country or spouse. ${ }^{7}$

Why do some philosophical trends consider patriotism a vice? How does one reconcile patriotism with general ethical principles that require all peoples, regardless of race or color, to be treated in the same way? MacIntyre observes that patriotism cannot be justified as a virtue on the grounds of the liberal concept of morality that has dominated Western thought over the last centuries. ${ }^{8}$ According to MacIntyre, “... what morality provides are standards by which all actual social structures may be brought to judgment from a standpoint independent of all of them. It is morality so understood allegiance to which is not only incompatible with treating patriotism as a virtue, but which requires that patriotism - at least in any substantial version - be treated as a vice. [...] According to the liberal account of morality where and from whom I learn the principles and precepts of morality are and must be irrelevant both to the question of what the content of morality is and to that of the nature of my commitment to it, as irrelevant as where and from whom I learn the principles and precepts of mathematics are to the content of mathematics and the nature of my commitment to mathematical truths."9

MacIntyre emphatically denies the liberal concept of morality. Referring to Aristotle, the American philosopher argues that one learn morals in the community in which he is raised. Therefore, where and

Ibid, 4-5.

See A. MacIntyre, A Short History of Ethics: A History of Moral Philosophy from the Homeric Age to the Twentieth Century (Indiana: Notre Dame Press, 1998), 122-127.

$9 \quad$ A. MacIntyre, Is Patriotism a Virtue?, 8. 
from whom one learns fundamental ethical principles has a decisive influence on the content of these principles as well as the nature of moral obligations. On the one hand, moral principles enacted within a concrete historical community are very similar and sometimes even identical to the rules that other communities follow. On the other hand, these moral principles are particular, since they arise out of a community's (one's homeland) unique historical experiences. In this context, one can treat patriotism as a virtue.

MacIntyre closely links the virtue of patriotism with the community as well as with a specific understanding of morality. MacIntyre's thoughts on patriotism are inspired by the Aristotle, who himself thought out the concept of virtue and analyzed the relationship between man and the community. According to MacIntyre, "loyalty to that community, to the hierarchy of particular kinship, particular local community and particular natural community, is on this view a prerequisite for morality. So patriotism and those loyalties cognate to it are not just virtues but central virtues." 10

\section{Considerations on Constitutional Patriotism}

Americans have commented extensively on MacIntyre's statements on patriotism. Europeans, however, are not very interested in what MacIntyre has to say on this subject. This is not to say, however, that a renaissance in patriotic attitudes is not occurring in Europe. On the contrary, patriotic attitudes can be clearly observed in Germany where, for example, a very serious discussion on German national consciousness began in 2004. ${ }^{11}$ At that time, the German President Horst Köhler's statement that he loved his country initiated this discussion. Up to then, "the president's honest statement had been unthinkable in the young Federal Republic of Germany. For this reason, when journalists asked Köhler's predecessor Gustav Heinemann if he loved his country, he replied, "I don't love my fatherland; I love my wife."12

During the past decade or so, a profound revival of national consciousness and a strengthening of patriotic attitudes have undoubtedly occurred. These changes are evident in the way that the mass and

$10 \quad$ Ibid, 11.

11 See P. Molt, "Abschied vom Verfassungspatriotismus? Dolf Sternberger und die aktuelle Debatte [Farewell to Constitutional Patriotism? Dolf Sternberger and the Current Debate]," Die Politische Meinung 435, no. 2 (2006): 29-36.

12 I. Janicka, Nowy niemiecki patriotyzm w debacie publicznej RFN [New German Patriotism in the Public Debate in Germany] (Poznan: 2007), 29. 
Moral theology

electronic media presents twentieth-century history and the crimes of the Third Reich. After the fall of the Third Reich in 1945, Germans were always aware of the unthinkable atrocities committed by their countrymen during World War II. Consequently, Germans consciously avoided any subjects related to patriotism and nationalism. It wasn't until 1959 that the German political thinker Dolf Sternberger used the term "constitutional patriotism" (der Verfassungspatriotismus) for the first time.$^{13}$ During the 1970s and 1980s, Sternberger's concept of love for one's country dominated the way that inhabitants of the Federal Republic of Germany approached their country. However, constitutional patriotism's influence on German society drastically declined in the 1990s, and today the German people have decidedly turned away from this concept. ${ }^{14}$

What is the essence of constitutional patriotism? Dolf Sternbergerthe originator of the concept of constitutional patriotism-was a student of the great German philosopher Karl Jaspers, who emphasized Germany's collective responsibility for war crimes and pointed out that Germany profoundly needed a new national, social, and state identity. Jaspers spoke outright of German guilt and demanded that a new democratic society free from the threats of nationalism, chauvinism, or xenophobia be established. ${ }^{15}$

Referring to Jasper's work and vision of a new German society, Sternberger proposed constitutional patriotism as the antidote to national patriotism. On the one hand, constitutional patriotism questions the patriotic attitudes that refer to the nation or homeland as a cultural and historical community. On the other hand, constitutional patriotism disagrees with completely rejecting the individual's connection to his own country - an idea characteristic of cosmopolitan thinking. In a certain sense, constitutional patriotism must protect the citizens of liberal democratic societies from the Scylla of nationalism and Charybdis of cosmopolitanism. According to Sternberger, patriotism arises from citizens' positive patriotic feeling toward, political attachment to, and identification with the democratic state and their desire to protect it

13 See B. Vogel, "Dolf Sternberger. Vater des Verfassungspatriotismus. Eine Würdigung zum 100. Geburtstag [Dolf Sternberger. Father of Constitutional Patriotism. A Tribute to the 100th Birthday]," Die Politische Meinung 452, no. 7 (2007): 69-72.

14 See S. Amato, Sul patriottismo costituzionale tedesco tra Settecento e Novecento [About the German Constitutional Patriotism between the Eighteenth and Twentieth Centuries] (Firenze: 2011).

15 See K. Jaspers, The Question of German Guilt (New York: Fordham University Press, 2001). 
against its enemies. Sternberger asserts that constitutional patriotism should not act as a surrogate of national patriotism. Instead, the essence of constitutional patriotism is to continue the European tradition of a patriotism that is connected with the state and its institutions.

While postwar German reflections on what caused the birth of National Socialism and the barbarism of the Third Reich have given way to a new version of patriotism, this does not mean that constitutional patriotism is exclusive to Germany; on the contrary, constitutional patriotism is universal. Sternberger proposes a new vision of the individual's relationship to his own state, which is possible in countries with liberal democracies that respect the constitutional order and institutions of the democratic state of law.

The concept of constitutional patriotism became very popular in the late 1980s. In 1986, the famous German philosopher Jürgen Habermas, who defined this form of love for one's country as a conscious support of the political principles and values contained in the constitution, began to use this term. Habermas argued that constitutional patriotism was an appropriate response to the problem of interpersonal relations among people as well as social integration into a multicultural and multiethnic contemporary liberal democracy. How does one create national unity in societies governed by liberal democracies? What is the source of social bonds? According to Habermas, the legal system is the only acceptable common ground for communication and values that will ensure stability and the rule of law in such societies, and the constitution should express the legal system's most basic values and principles.

At present, however, this is no longer the case. After the unification of Germany, this version of patriotism ceased to serve as a contrast to national patriotism. When the Berlin Wall fell, public discourse throughout Europe returned to the concept of the nation or homeland. Today, people refer to constitutional patriotism when speaking about an individual's relationship to transnational political structures. However, in the case of German or other European countries, discussions about constitutional patriotism reveal a revival of national consciousness and a return to the different concepts of love of one's own country.

\section{Patriotism in Social Ethics}

Studies on social ethics provide many valuable observations on the topic of love for one's country. Polish philosopher Tadeusz Ślipko is one of the most important social ethicists to write on the subject of 
Moral theology

patriotism. According to him, each individual has different duties to his country. These duties can be divided into "large" and "small" obligations, respectively. Large obligations pertain more to exceptional situations in which fidelity to one's nation demands true service to national matters and great efforts to support national interests. Such service requires sacrifice, risks to one's life and health, and even death. Ślipko argues that large obligations pertain particularly to the defense of one's homeland or state when a foreign nation or external entity threatens the freedom, well-being, and existence of one's own nation. ${ }^{16}$

What are an individual's "small" duties toward his country? These small obligations pertain to daily behaviors, through which one consciously affirms his homeland and cultivates its culture (language, literature, history, religion, tradition, social and state organizations, etc.). From among these moral attitudes, it is possible to distinguish three: patriotism, fidelity to one's nation, and love for one's homeland. Tadeusz Ślipko observes that:

Patriotism is occasionally identified with the obligation to be faithful to one's nation. At other times, however, patriotism strives for a deeper expression of solidarity that is more self-aware and that reaches the depth of the affections. This form of solidarity is expressed in a person's deep spiritual attachment to his country, in his full experience of his nation's culture, and, above all else, in his active involvement in national matters. ${ }^{17}$

Ślipko distinguishes patriotism from the moral virtue of love for one's country. How does one define love for one's country? Love for one's homeland is separate than patriotism because it is a personal moral virtue that has a richer axiological content because of its assumption that the homeland is partly a different social category than the nation insofar as love for one's homeland involves the constant and necessary component of the relationship between the nation and the values of the country that is within it. "Love for one's homeland is a virtue that shows man the moral nobleness and significance of these experiences for his personal development and enjoins him to consciously cultivate this virtue. The moral aspect of patriotism involves the whole power of man's attachment to the land of his birth land as well as his extricable relationship with it. ${ }^{18}$

\footnotetext{
16 See T.Ślipko, “Zarys etyki szczegółowej,” Etyka społeczna, Vol.2(Cracow:2005), 241-242.

17 Ibid, 242.

18 Ibid, 242-243.
} 
Unfortunately, Ślipko's analyses of patriotism and love for one's homeland do not consider the "Solidarity" movement, which began in 1980 and is a significant element of the Polish historical experience. ${ }^{19}$ One very important dimension of this movement was its ability to revive patriotic attitudes in Poland and establish a new ethos among the people. Therefore, it is impossible to speak about Polish patriotism without referring to the history of "Solidarity," especially during the first phase of existence from 1980 to 1981. Likewise, Polish philosophers have not yet analyzed the history of "Solidarity" from the perspective of the history of ideas. Such a philosophical analysis would shed light on the different ideological trends of this social movement-trends that are the key to understanding the current political disputes that are tearing apart the national Polish community. ${ }^{20}$

\section{Conclusion}

The revival of patriotic attitudes and the strengthening of national consciousness, which have been observed in Poland and in many other countries in recent years, are very positive phenomena that indicate a global cultural trend. Love for one's country and respect for one's native culture and traditions do not pertain only to one's past and to historical research. Rather, they are closely related to a current capacity for sacrificial and solidary building up of the common good. Consequently, the right approach to patriotism has a real impact on the shape of our future at national and international levels.

Disputes over the moral value of patriotism have been going on for centuries. Unfortunately, not every form of patriotism can be considered a virtue. Not all versions of love for one's own country are good and useful. Throughout history, there have been two opposing views of patriotism to which contemporary thinkers refer. On the one hand, there are those who support patriotism, and Roman poet Horace represents this group. In the first century before Christ, he called on the Roman citizens to fight the Persians, saying: "Dulce et decorum est pro patria mori - It is sweet and honorable to die for one's country."

$19 \quad$ See A. Kobyliński, "Nadzieja i zdrada 'Solidarności' [Hope and Betrayal of 'Solidarity']," W Sieci 21 (2016): 54-55; Idem, "Dzieje 'Solidarności' i wojna idei [The History of "Solidarity" and the War of Ideas]," W Sieci 35 (2016): 66-68.

20 See A. Kobyliński, "The Role of Solidarity in an Open Society," Europske kontexty interkulturnej komunikacie, eds. P. Ivanic, M. Hetenyi, Z. Taneski (Nitra: 2009), 139-148; A. Kobyliński, "Tischner and Metz: two Understandings of Solidarity," Transformacia ludskej identity $v$ strednej Europe po roku 1990, ed. H. Hrehova (Trnava: Filozofická fakulta TU, 2009), 45-51. 
Moral theology

On the other hand, there is a group that opposes patriotism, the representative of which is the well-known Russian writer Leo Tolstoy. Tolstoy believed that patriotism is a moral error, or grave sin, that opposes the basic principles of Christian morality, which rejects both individual and group egoism because our neighbor is simply human. From this point of view, patriotism is another form of moral relativism, which ultimately assesses behavior based on who is acting, in relation to whom he is acting, and for what reasons. In this century, Horace's ideas have been more widely accepted than Tolstoy's concept of love for one's own country. Today, an increasing revival of national patriotism is taking place in many countries. Due to changing cultural trends, public opinion has reflected more on Alaisdair MacIntyre's central virtue of patriotism than on Dolf Sternberger or Jürgen Habermas' vision of constitutional patriotism.

According to the American example of patriotism, love for one's country should always be open and inclusive. All forms of racism and xenophobia are foreign to the true virtue of patriotism. If a country is to wisely and responsibly foster patriotic attitudes, then national selfishness and nationalism, which cultivate a sense of superiority by closing the nation off to other national communities and the universal community, should be eliminated. Nationalism, particularly in its more radical forms, is the antithesis of true patriotism. Therefore nations in Europe and elsewhere should not permit extreme nationalism to give rise to new forms of the totalitarian vision of social and political life. ${ }^{21}$

Today, populism poses a serious threat to democracy's effective functioning and individuals' proper relationship to their own country. In recent years, political and economic crises have paved the way for ideological movements that demagogically emphasize the will of the people and their attachment to their homeland to spring up in many countries. Many elements of populism radically oppose love for one's country. ${ }^{22}$ For this reason, in the years ahead, populist trends will present serious challenges to those countries that defend democracy and the virtues of patriotism.

Patriotism in Poland wisely combines tradition and modernity. Therefore, on the one hand, Poles should strive to preserve the beautiful elements of the romantic patriotic attitudes described by literary figures such as Adam Mickiewicz and Henryk Sienkiewicz. On the

21 See A. Walicki, Naród, nacjonalizm, patriotyzm [Nation, Nationalism, Patriotism] (Cracow: Universitas, 2009).

22 See. D. Palano, "Populismo. Paradosso della democrazia [Populism. Paradox of Democracy]," Avvenire 50, no. 89 (2017): 20. 
other hand, Poles should not fail to consider the virtue of patriotism from a philosophical point of view. Only through deeper intellectual reflection can Poles bring their patriotic traditions to the global debate on Dolf Sternberger, Alaisdair MacIntyre, or Jürgen Habermas' ideas of patriotism.

\section{JAKI PATRIOTYZM JEST CNOTĄ? MEANDRY MIŁOŚCI DO WŁASNEGO KRAJU}

Głównym celem artykułu jest prezentacja kilku wybranych koncepcji filozoficznych patriotyzmu oraz nakreślenie szerszego kontekstu współczesnych sporów, prowadzonych w wielu krajach, dotyczących właściwego rozumienia relacji człowieka do własnego narodu, państwa i ojczyzny. Przez wiele stuleci fenomen patriotyzmu nie był przedmiotem zainteresowania myśli filozoficznej. Ta sytuacja uległa diametralnej zmianie w ostatnich dziesięcioleciach. W tym okresie zagadnienie patriotyzmu zostało podjęte przez takich myślicieli jak Dolf Sternberger, Alasdair Maclntyre, Jürgen Habermas czy Igor Primoratz. Obecnie patriotyzm jest tematem debaty nie tylko w filozofii moralnej, ale także w różnego rodzaju teoriach politycznych. Potwierdzeniem zainteresowania patriotyzmem ze strony filozofii polityki jest m.in. spór prowadzony między komunitarystami a przedstawicielami myśli liberalnej.

Słowa kluczowe: patriotyzm, patriotyzm narodowy, patriotyzm konstytucyjny, ojczyzna, naród, nacjonalizm, solidarność, demokracja, etyka społeczna.

\section{Bibliography:}

1. Amato, S. Sul patriottismo costituzionale tedesco tra Settecento e Novecento [About the German Constitutional Patriotism between the Eighteenth and Twentieth Centuries]. Firenze: 2011.

2. Janicka, I. Nowy niemiecki patriotyzm w debacie publicznej RFN [New German Patriotism in the Public Debate in Germany]. Poznan: 2007.

3. Jaspers, K. The Question of German Guilt. New York: Fordham University Press, 2001.

4. Kiernan, S. P. Authentic Patriotism: Restoring America's Founding Ideals Through Selfless. New York: St. Martin's Press, 2010.

5. Kobos, A. M. Editor. Patriotyzm wczoraj i dziś [Patriotism Yesterday and Today]. Cracow: Seminarium PAU, 2008.

6. Kobyliński, A. "Dzieje 'Solidarności' i wojna idei [The History of "Solidarity" and the War of Ideas]." W Sieci 35 (2016): 66-68.

7. Kobyliński, A. "Nadzieja i zdrada 'Solidarności' [Hope and Betrayal of 'Solidarity']." W Sieci 21 (2016): 54-55. 
Moral theology
8. Kobyliński, A. "The Role of Solidarity in an Open Society." In Europske kontexty interkulturnej komunikacie. Edited by P. Ivanic, M. Hetenyi, Z. Taneski. Nitra: 2009, 139-148.

9. Kobyliński, A. "Tischner and Metz: two Understandings of Solidarity." In Transformacia ludskej identity $v$ strednej Europe po roku 1990. Edited by H. Hrehova. Trnava: 2009, 45-51.

10. Król, M. Patriotyzm przyszłości [Patriotism of the Future]. Warsaw: Rosner i Wspolnicy, 2004.

11. MacIntyre, A. A Short History of Ethics: A History of Moral Philosophy from the Homeric Age to the Twentieth Century. Indiana: Notre Dame Press, 1998.

12. MacIntyre, A. Is Patriotism a Virtue? Kansas: University of Kansas Press, 1984.

13. Mangena, F. “Aristotle, Patriotism, and Reason: Reflections of MacIntyre's Question - Is Patriotism a Virtue?" Phronimon 11, no. 2 (2010): 5-48.

14. Molt, P. "Abschied vom Verfassungspatriotismus? Dolf Sternberger und die aktuelle Debatte [Farewell to Constitutional Patriotism? Dolf Sternberger and the Current Debate]." Die Politische Meinung 435, no. 2 (2006): 29-36.

15. Palano, D. "Populismo. Paradosso della democrazia [Populism. Paradox of Democracy]." Avvenire 50, no. 89 (2017): 20.

16. Primoratz, I. Patriotism. New York: Humanity Books, 2002.

17. Rosati, M. Il patriottismo italiano. Culture politiche e identità nazionali [Italian Patriotism. Political Cultures and National Identities]. Rome: Bari, 2000).

18. Ślipko, T. “Zarys etyki szczegółowej.” Etyka społeczna, Vol. 2. Cracow: 2005, 241-242.

19. Vogel, B. "Dolf Sternberger. Vater des Verfassungspatriotismus. Eine Würdigung zum 100. Geburtstag [Dolf Sternberger. Father of Constitutional Patriotism. A Tribute to the 100th Birthday]." Die Politische Meinung 452, no. 7 (2007): 69-72.

20. Walicki, A. Naród, nacjonalizm, patriotyzm [Nation, Nationalism, Patriotism]. Cracow: Universitas, 2009. 